\title{
Clinical symptoms and laboratory data in newborn foals with sepsis - a retrospective analysis
}

\author{
A. Sobiraj, Kerstin Herfen' and H. Bostedt \\ Ambulatorische und Geburtshilfliche Tierklinik, Veterinärmedizinische Fakultät, Universitäł Leipzig, \\ 'Klinik für Geburtshilfe, Gynäkologie und Andrologie der Groß- und Kleintiere mił Tierärztlicher Ambulanz, Fachbereich Veterinärmedizin, Justus Liebig Universität Gießen
}

\begin{abstract}
Summary
146 newborn foals aged 12 hours to 14 days with varying manifestations of sepsis were retrospectively analysed, based on a modified sepsisscoring system with respect to historical data, clinical findings and laboratory data (IgG, glucose, number of neutrophilic granulocytes in the blood). The overall cure rate was $13 \%(19 / 146)$. The majority of foals $(60 \%)$ presented to the clinic were highly depressed $(34 / 146)$ or comatose $(66 / 146)$. Foals with early signs of sepsis, but still able to stand and with a positive suckling reflex $(46 / 146)$ had much better survival rates $(30 \%)$, whereas recumbent patients with positive suckling reflex had lowered prognosis quoad vitam (15\%). The foals which entered the clinic in a comatose status could not be cured in any case. With respect to history and results of the clinical examination immature and/or underdeveloped septic foals had the poorest prognosis. Obviously one of the main reasons for septicaemia was an inadequate intake of colostral immunoglobulins: $60 \%$ of the foals showed a hypogammaglobulinaemia with lgG-concentrations $<400 \mathrm{mg} / \mathrm{dL}$. Their survival rate was $<10 \%$, whereas foals with lgG levels $>400 \mathrm{mg} / \mathrm{dL}$ had improved cure rates $(24 \%)$. Foals with granulocytopenia $(<2000 / \mathrm{mm} \approx)$ or granulocytosis $(>12.000 / \mathrm{mm} \approx)$ as well as hypoglycaemic foals $(<40 \mathrm{mg} / \mathrm{dL}$ ) showed reduced cure rates. Most infections occurred post natum: Common environmental bacteria like E. coli, A. equuli, Klebsiella spec., Sc. zooepidemicus, Salmonella spec. and Staph. aureus were isolated most frequently.
\end{abstract}

Keywords: $\quad$ newborn foals, sepsis, clinical signs, laboratory data, cure rate

\section{Klinik und Labordiagnostik bei neugeborenen Fohlen mit Sepsis - eine retrospektive Auswertung}

Bei 146 Fohlen im Alter zwischen 12 Stunden und 14 Tagen mit verschiedener Ausprägung einer Sepsis wurden die vorberichtlichen, klinischen und labordiagnostischen Daten in Anlehnung an einen etablierten Sepsis-Score retrospektiv analysiert. Die Gesamtheilungsrate betrug 13\% (19/146). Die Mehrheit der Fohlen (60\%) wies zum Zeitpunkt der Einlieferung in die Klinik eine mittelgradige Depression als Folge fortgeschrittener Sepsis auf (34/146), beziehungsweise befand sich bereits im komatösen Zustand (66/164). Fohlen, die sich zum Zeitpunkt der Einlieferung noch in der Frühphase der Septikämie befanden, erkenntlich unter anderem an vorhandenem Stehvermögen und vorhandenem Saugreflex, wiesen mit 30\% die höchste Heilungsrate auf, während bereits festliegende Patienten mit noch positivem Saugreflex mit 15\% eine deutlich schlechtere Überlebensrate aufwiesen. Dagegen konnte keines der komatösen Fohlen (66/164) geheilt entlassen werden. Die Prognose bei Fohlen, welche klinisch Anzeichen der Unreife und/oder der Unterentwicklung aufwiesen, war die schlechteste. 60\% der Fohlen wiesen IgGWerte im Blut von unter $400 \mathrm{mg} / \mathrm{dl}$ auf, waren folglich hypogammaglobulinämisch. Deren Überlebensrate betrug weniger als $10 \%$, während Fohlen mit lgG-Konzentrationen $>400$ mg/dl lgG im Blut zu über 20\% geheilt werden konnten. Bei Vorliegen einer Granulozytopenie $(<2.000 / \mathrm{mm} \approx)$, gleichermaßen bei Granulozytosen (>12.000/mm $\approx$ ), war die Prognose quoad vitam erheblich schlechter als bei Patienten, die Normalwerte bzw. leicht erhöhte oder leicht erniedrigte Granulozytenzahlen im Blut aufwiesen. Das Vorliegen einer Hypoglykämie (<40 $\mathrm{mg} / \mathrm{dll}$ ) wirkte sich ebenfalls stark mindernd auf die Heilungsrate aus. Überwiegend waren die Infektionen post natum aufgetreten: So dominierten ubiquitäre fakultativ pathogene gram-negative und gram-positive Bakterien, wie E. coli, Klebsiellen, A. equuli., Sc. zooepidemicus, Salmonellen und Staph. aureus.

Schlüsselwörter: neugeborene Fohlen, Sepsis, Klinik, Labordiagnostik, Heilungsrate

\section{Introduction}

Septicaemia is a systemic disease characterized by the presence of pathogenic microorganisms and/or their toxins in the blood. $33 \%$ of foal mortality is attributed to bacterial infections (Platt, 1973, Koterba et al., 1984, Brewer, 1990, Freeman and Paradis, 1992, Paradis, 1994). In foals younger than 14 days it is one of the most common disorders. The possible routes of infection are via placenta during pregnancy and sub partu due to bacterial cervicitis and/or vaginitis of the mares. However, most cases of sepsis occur after birth via oral, airborne or omphalogenic infection of the foal with facultative pathogenic bacteria most likely in correlation with an inadequate lgG-intake and/or -transfer. The presuckle foal is essentially agammaglobulinaemic. In consequence, each disturbance of suckling colostrum mainly within the first 12 hours post natum is followed by a high risk of systemic bacterial infection. These disturbances may be caused by depression of vitality, weakness after dystocia, immaturity, reduced birth weight and underdevelopment. The aim of the study was to summarize anamnesis, clinical and laboratory data of septic foals with special regard to the survival rates.

\section{Animals, materials and methods}

146 foals (67 male, 79 female) with signs of sepsis aged 12 hours to 14 days presented to the obstetric clinics of Gießen and Leipzig were analysed. To diagnose or exclude "sepsis" a modified scoring system originally established by Brewer and Koterba (1988) was used. It is based on the following three 
main parts: history of the mare including parturition (gestation length; vulvar discharge during pregnancy; sickness of the mare during pregnancy; shortened/prolonged gestation length; induction of parturition; dystocia; death of the mare after parturition; hypo-, agalactia; prepartum loss of milk; nonacceptance of the newborn foal), complete clinical examination of the foal (prematurity; low birth weight including twins, underdevelopment; ability/inability to stand; positive/ negative suckling reflex; body temperature; colour of mucous membranes; specific clinical indicators of bacterial infection like arthritis, bronchitis, pneumonia, septic meningitis, diarrhea, open wounds, uveitis anterior), and laboratory data from the blood (lgG-concentration: semi-quantitative test kit/total; number of neutrophilic granulocytes; blood glucose concentration). All bacteriologic specimen were obtained from necropsy material, while in vivo blood cultures were not carried out.

\section{Results and discussion}

The overall survival rate was 13\% (19/146). The other foals died or had to be euthanized, in most cases after intensive care of the foals including systemic antibiotic therapy, infusions with glucose, plasma-, electrolyte- and/or buffer-solutions, insufflation of oxygene-riched air and tube feeding. 60\% (89/146) of the foals were younger than 2 days and had a 15\% survival rate, 30\% $(42 / 146)$ entered the clinics at the age of 2 to 7 days, $12 \%$ of them survived. $10 \%(15 / 146)$ of the patients were aged between 8 and 14 days, from this group only one foal could be cured. Most of the foals were pre-treated by veterinary surgeons and after that transferred to the clinic. The summary of historical, clinical and laboratory data is shown in table 1. With special regard to the anamnesis and the results of the clinical examination, premature foals $(41 / 146)$ and mature, but underdeveloped foals had the worst prognosis quoad vitam: none of them survived. The ability/inability to stand in combination with a positive/ negative suckling reflex were useful prognostic indicators: Foals being able to stand and to suckle are in an early phase of sepsis representing a hyperdynamic cardiovascular state. Foals in lateral recumbency with missing suckling reflex are in precoma or deep coma, the second stage of septicaemia due to septic shock with generalized hypodynamic characteristics. 46 of 146 foals were able to stand, the cure rate was 30\% (14/46), whereas from 34 foals which were recumbent with positive suckling reflex, 15\% (5/34) survived. Nearly one half of the septic foals (66/146) arrived in the clinic showing signs of a comatose septic shock and no suckling reflex. None of them could be treated successfully. Pale $(n=14)$, icteric $(n=13)$ or cyanotic $(n=7)$ mucous membranes, also indicating the progressive stage of septicaemia, were correlated with a poor prognosis, since none of the foals survived. Cure rates were much better in patients revealing early stages of bacterial diseases with normal (8/38) or deeply red coloured (74/146) mucous membranes, as 11 of these foals survived. The authors propose that the sepsis scoring system from Brewer and Koterba (1988) probably should pay more respect to this phenomenon.

More than $50 \%$ of the foals revealed normal values concerning the body temperature $(77 / 146)$ combined with a markedly
Tab. 1: History and clinical conditions in septicaemic foals, arriving at the clinic

Vorberichte und klinische Befunde bei Fohlen mit Sepsis zum Zeitpunkt der Einlieferung

\begin{tabular}{|c|c|c|}
\hline Anamnestic data & Cases (\%) & Cured (\%) \\
\hline Loss of milk several days before parturition & 2 & 0 \\
\hline Shortened gestation length ( $<310$ days) & $25+?$ & 0 \\
\hline Prolonged gestation length (>365 days) & 2 & 0 \\
\hline Dystocia & $4+?$ & 0 \\
\hline Agalactia/hypogalactia of the mare & 3 & 0 \\
\hline Induced parturition & 2 & 0 \\
\hline Death of the mare during/after parturition & 2 & 0 \\
\hline \multicolumn{3}{|l|}{ Clinical findings } \\
\hline Able to stand/positive suckling reflex & $46(31.5)$ & $14(30)$ \\
\hline Unable to stand/positive suckling reflex & $34(23)$ & $5(15)$ \\
\hline $\begin{array}{l}\text { Unable to stand/negative suckling reflex } \\
\text { (= coma) }\end{array}$ & $66(45)$ & $0(0)$ \\
\hline Body temperature $<37.2 \infty \mathrm{C}$ & $41(28)$ & $1(2)$ \\
\hline Body temperature $37.2-39.1 \infty \mathrm{C}$ & $77(53)$ & 15 (19) \\
\hline Body temperature $>39.10 \mathrm{C}$ & 28 (19) & $3(11)$ \\
\hline Mucous membranes, "physiological" & $38(26)$ & $8(21)$ \\
\hline Mucous membranes, red & $74(51)$ & $11(15)$ \\
\hline Mucous membranes, pale & 14 & 0 \\
\hline Mucous membranes, icteric & 11 & 0 \\
\hline Mucous membranes, red and icteric & 2 & 0 \\
\hline Mucous membranes, cyanotic & 7 & 0 \\
\hline Prematurity + EHV-infection & $39+3(29)$ & 0 \\
\hline $\begin{array}{l}\text { Mature but weak/reduced weight / } \\
\text { underdevelopment }\end{array}$ & $41(28)$ & $5(14,5)$ \\
\hline Swollen joints (arthritis), open wounds & $22(15)$ & $6(27)$ \\
\hline Bronchopneumonia, bronchitis & $17(12)$ & $3(18)$ \\
\hline Diarrhea & $9(6)$ & $3(33)$ \\
\hline White muscle disease & 7 & 2 \\
\hline Maladjustment syndrome & 2 & 0 \\
\hline Meningoencephalitis & 1 & 0 \\
\hline Omphalitis & 2 & 0 \\
\hline Other clinical abnormalities & 3 & 0 \\
\hline
\end{tabular}


higher survival rate (19.5\%) compared with the foals having elevated body temperature $\left(>39.0^{\circ} \mathrm{C} ; n=28 / 146\right)$, which could be cured in only $11 \%$ of the cases. Foals presenting a generalized hypo-dynamic situation characterized by a lowered body temperature $\left(<37.2^{\circ} \mathrm{C} ; \mathrm{n}=41 / 146\right)$, mostly combined with cold extremities and prolonged capillary refilling time, had a significantly reduced survival rate: Only one foal left the clinic alive. The sepsis score from Brewer and Koterba (1988) gives two scoring points for fever, but only one for lowered body temperature. Considering our own investigations, it has to be discussed, whether the scoring points should be exchanged.

Regarding the lgG-concentrations in the blood of septic foals, our results are in complete accordance with other reports: The critical value which differentiates between normo- and hypogammaglobulinaemia was $400 \mathrm{mg} / \mathrm{dL}$. Patients showing decreased lgG-values (45/102: <200 mg/dL; 12/102: > 200 $400 \mathrm{mg} / \mathrm{dL}$ ) had a survival rate of $10 \%$, whereas foals with lgG-levels $>400 \mathrm{mg} / \mathrm{dL}(45 / 102)$ showed a higher cure rate of $24 \%$ (table 2).

With respect to the number of neutrophilic granulocytes either foals with a marked granulocytosis (>12.000/mm $\approx, 18 / 126)$, indicating the acute phase of sepsis, or those showing a marked neutropenia $(<2.000 / \mathrm{mm} \approx, 42 / 126)$, indicating collapse of the resistance mechanisms, had a bad prognosis. Patients with moderately elevated or reduced numbers of neutrophils and those with normal values had much better survival rates.

Tab. 2: Laboratory data in septicaemic foals, arriving at the clinic Laborwerte bei Fohlen mit Sepsis zum Zeitpunkt der Einlieferung

\begin{tabular}{|c|c|c|}
\hline Laboratory data & $\begin{array}{c}\text { Cases } \\
(\%)\end{array}$ & $\begin{array}{c}\text { Cured } \\
(\%)\end{array}$ \\
\hline $\lg G$-concentration in blood' $(\mathrm{mg} / \mathrm{dL})<200$ & 45 & $6(13)$ \\
\hline $\lg G$-concentration in blood (mg/dL) 200ñ400 & 12 & $0(0)$ \\
\hline $\operatorname{lgG}$-concentration in blood (mg/dL) 400ñ800 & 15 & $3(20)$ \\
\hline $\lg$-concentration in blood $(\mathrm{mg} / \mathrm{dL})>800$ & 30 & $8(27)$ \\
\hline Number of neutrophils $\leq$ (per $\mathrm{mm} \geq$ ) $<2.000$ & $42(41)$ & $3(7)$ \\
\hline Number of neutrophils (per $\mathrm{mm} \geq$ ) 2.000ñ4.000 & $24(23)$ & $8(33)$ \\
\hline Number of neutrophils (per $\mathrm{mm} \geq$ ) 4.000ñ 8000 & $23(22)$ & $2(9)$ \\
\hline Number of neutrophils (per $m m \geq$ ) 8.000ñ 12.000 & $19(18)$ & $5(26)$ \\
\hline Number of neutrophils (per $m m \geq$ ) $>12.000$ & $18(17)$ & $1(5,5)$ \\
\hline Glucose in blood $\geq(\mathrm{mg} / \mathrm{dL})<10$ & 28 (19) & $0(0)$ \\
\hline Glucose in blood (mg/dL) $1 \tilde{n} 40$ & $35(24)$ & $1(3)$ \\
\hline Glucose in blood (mg/dL) 40ñ80 & $29(20)$ & $4(14)$ \\
\hline Glucose in blood (mg/dL) 80ñ 120 & $23(16)$ & $5(22)$ \\
\hline Glucose in blood $(\mathrm{mg} / \mathrm{dL})>120$ & $28(20)$ & $9(32)$ \\
\hline
\end{tabular}

'total number of cases: 102; "total number of cases: 126; $\approx$ total number of cases: 143
In accordance with the sepsis score from Brewer and Koterba (1988) foals with a severe hypoglycaemia $<40 \mathrm{mg} / \mathrm{dL}$ (63/ 143) had a poor prognosis quoad vitam: only one foal survived, whereas those patients with moderate hypoglycaemia (40-80 $\mathrm{mg} / \mathrm{dL}$ ) had a better prognosis (29/143; 4 foals cured). Normoglycaemic foals with concentrations of blood glucose $>80 \mathrm{mg} / \mathrm{dL}(54 / 143)$ showed a cure rate of $31 \%$.

In no case in vivo blood cultures were taken, but the bacteriological results obtained from necropsy material confirmed the clinically suspected sepsis. In agreement with other reports (Platt, 1973, Koterba et al., 1984; Oikawa et al., 1991, Paradis, 1994), Escherichia coli was isolated most frequently $(n=24)$, followed by Actinobacillus equuli $(n=8)$, Klebsiella species $(n=5)$, Streptococcus zooepidemicus $(n=3)$, Staphylococcus aureus $(n=2)$ and Salmonella species $(n=2)$, indicating that most foals with hypo- or agammaglobulinaemia were infected post natum. In conclusion, sepsis in newborn foals shows variable historical, clinical and laboratory diagnostic features. Survival rates in this investigation were low, although most of the patients were immediately therapied including intensive care. A possible explanation for better cure rates in other reports (Koterba et al., 1984, Paradis, 1994) may be that most of the foals entering the clinics in our study were already in the prefinal status of a systemic infection. This is probably due to a poor sensitivity of the horse keepers to call for a veterinarian as soon as a newborn foal shows minimal deviations from normal postnatal development.

\section{Literature}

Brewer, Barbara D. (1990): Neonatal infection. In: Koterba, A.M., Drummond, W.H., Kosch, P.C. (eds.): Equine Clinical Neonatology, Philadelphia, Lea \& Febiger, 295-316

Brewer, Barbara D., Koterba and Anne M. (1988): The development of a scoring system for the early diagnosis of equine neonatal sepsis. Equine Vet. J. 20, 18-22

Freeman, L. and Paradis, Mary R. (1992): Evaluating the effectiveness of equine neonatal care. Vet. Med. 87, 921-926

Koterba Anne M., Brewer, Barbara D. and Tarplee, F. A. (1984): Clinical and clinicopathological characteristics of the septicaemic neonatal foal: Review of 38 cases. Equine Vet. J. 16, 376-383

Oikawa, M.-A., Kamada, M., Yoshihara, T., Kaneko, M. and Yoshikawa T. (1991): Clinico-pathological analysis of foal diseases from 237 autopsy cases. Kitasato Arch. Exp. Med. 64, 149-156

Platt, H. (1973): Etiological aspects of perinatal mortality in the Thoroughbred. Equine Vet. J. 5, 116-120

Paradis, Mary R. (1994): Update of neonatal septicemia. Vet. Clin. North Am.: Equine Practice 10, 109-135

\section{Prof. Dr. Axel Sobiraj}

Ambulatorische und Geburtshilfliche Tierklinik

Veterinärmedizinische Fakultät

Universität Leipzig

An den Tierkliniken 29

D-04103 Leipzig

Germany

Tel.: 0049-341-97-38490 / 38491

Fax.: 0049-341-97-38398

e-mail:sobirai@vetmed.uni-leipzig.de 